\title{
SISTEM EKONOMI KAPITALIS
}

\author{
Nur Asia (90100118093)
}

\section{ochiena98@gmail.com}

Ilmu ekonomi lahir dari adanya tujuan untuk mengalokasikan dan menggunakan sumber daya yang terbatas. Karena kelanggkaan inilah kemudian setiap individu akan dihadapkan pada berbagai pilihan tentang apa yang harus diproduksi, bagaimana memproduksinya, untuk siapa, bagaimana membagi produksi dari waktu kewaktu serta bagaimana mempertahankan dan menjaga tingkat pertumbuhan produksi tersebut. Sistem ekonomi yang dikenal oleh masyarakat secara global adalah sistem ekonomi kapitalis dan sosialis. Sistem kapitalis dipengaruhi oleh semangat mendapatkan keuntungan semaksimal mungkin dengan sumber daya yang terbatas. Sistem ekonomi yang dikenal oleh masyarakat secara global adalah sistem ekonomi kapitalis dan sosialis. Sistem kapitalis dipengaruhi oleh semangat mendapatkan keuntungan semaksimal mungkin dengan sumber daya yang terbatas. Usaha kapitalis ini didukung oleh nilai-nilai kebebasan untuk memenuhi kebutuhan. Kebebasan ini mengakibatkan tingginya persaingan diantara sesamanya untuk bertahan. Sistem ekonomi kapitalis memiliki beberapa kecenderungan antara lain : kebebasan memiliki harta secara perorangan, kebebasan ekonomi dan persaingan bebas, serta ketimpangan ekonomi. Sedangkan sistem ekonomi sosialis mempunyai tujuan kemakmuran bersama. Filosofi ekonomi sosialis, adalah bagaimana bersama-sama mendapatkan kesejahteraan. Ciri-ciri ekonomi sosalis diantaranya: pemilikan harta oleh negara, kesamaan ekonomi, dan disiplin politik.(Masykuroh 2005)

Sistem ekonomi kapitalis menjadi system ekonomi yang mendominasi dari sistem ekonomi yang dipakai negara-negara saat ini. Meskipun dengan perkembangan teknologi dan informasi atau IT yang begitu dahsyat saat ini, boleh dikatakan tidak ada sistem ekonomi kapitalis murni, karena di negara-negara kapitalis lebih sosialis dibandingkan dengan negara-negara yang menggunakan sistem ekonomi sosialis itu sendiri. Sistem perkonomian merupakan sebuah skema yang digunakan suatu negara tertentu di dalam memecahkan persoalan-persoalan ekonomi yang dialami oleh negara tersebut, agar persoalan ekonomi itu dapat teratasi, jangan sampai dengan adanya sistem ekonomi justru menambah masalah atau persoalan ekonomi suatu negara, walaupun jika ditinjau, sampai saat ini belum ada sistem ekonomi yang sempurna yang mampu menyelesaikan persoalan bangsa khususnya dalam hal keadilan dan pemerataan bagi masyarakatnya yang ada.(Tho' in 2015)

Dalam semua definisi imperialisme, ada beberapa konsep yang selalu muncul: perluasan wilayah, penguasaan atau dominasi dengan paksaan (coercion), dan dominasi politik, budaya, serta ekonomi. V.I. Lenin menyatakan bahwa kapitalisme mencakup kapitalisme monopoli sebagai imperialisme untuk menemukan bisnis dan sumber daya baru. Ketika monopoli kapital finansial mendominasi, memaksa negara dan korporasi swasta bersaing untuk mengontrol sumber daya alam dan pasar.3 Kolonialisme sebagai salah satu aspek prahistori moda produksi kapitalis. Selain itu, teori imperialisme Marxist, dan teori dependensi yang terkait, menekankan pada hubungan ekonomi antar-negara (dan didalam negara-negara), alih-alih hubungan formal politik dan militer. Dengan begitu, imperialisme tidak selalu berupa satu hubungan kontrol yang formal satu negara 
atas negara lain, melainkan eksploitasi ekonomi satu negara atas negara lain. Dalam periodisasi yang lazim, imperialisme dibagi menjadi dua periode. (Finance 2008)

Kapitalisme merupakan sebuah sistem organisasi ekonomi yang dicirikan oleh hak milik privat atas alat-alat produksi dan distribusi yang pemanfaatannya untuk mencapai laba dalam kondisi yang sangat kompetitif (Milton H. Spencer;1990).Selajutnya pengertian sistem ekonomi kapitalis adalah suatu sistem yang memberikan kebebasan yang cukup besar bagi pelaku-pelaku ekonomi untuk melakukan kegiatan yang terbaik bagi kepentingan individual atas sumberdaya-sumberdaya ekonomi atau faktor-faktor produksi. Pada sistem ekonomi ini terdapat keleluasaan bagi perorangan untuk memiliki sumberdaya, seperti kompetisi antar individu dalam memenuhi kebutuhan hidup, persaingan antar badan usaha dalam ekonomi mencari keuntungan. (Agustiati 1929)

Masykuroh, Nihayatul. 2005. "Sistem Ekonomi Kapitalis, Sosial Dan Islam.” Alqalam 22 (1): 101. https://doi.org/10.32678/alqalam.v22i1.1446.

Tho'in, Muhammad. 2015. 'Konsep Ekonomi Islam Jalan Tengah (Kapitalis - Sosialis)." Jurnal Ilmiah Ekonomi Islam 1 (03): 118-33. https://doi.org/10.29040/jiei.v1i03.34.

Financial Times, London, 21 Maret 1994 George

Agustiati. 1929. "Sistem Ekonomi Kapitalisme.” Sistem Ekonomi Kapitalisme, 152-66. 